\title{
The Implementation of Teachers' Humor in The Classroom
}

\author{
Masdianti \\ Universitas Sawerigading Makassar \\ masdianti.unsa@gmail.com
}

\begin{abstract}
This research aims to investigate what types of teachers' humor in teaching English, find out the function of teachers' humor, and analyze the effect of teachers' humor on students' enthusiasm in learning English. This research applied a qualitative research design. The subjects of this research were English teachers of the English Language Center (ELC). In collecting the data, this research took place in the classroom for six meetings during the classroom interactions, particularly in 90 minutes of English lesson for each teacher. The data of the study were obtained by observing the learning and teaching activity in the classroom and interviewing the teachers and some students to know more about their perception of the learning process. The data were analyzed to identify the data from the observation, recorder, and interview. The result showed that the teacher used seven types of humor during the teaching and learning process: joke, pun, funny story, humorous comment, physical humor, satire, and riddle. In this research, the researcher found that the teachers used humor for three functions: coping with stress, drawing students' attention, and facilitating communication. And there were five effects of teachers' humor related to students' enthusiasm in the classroom; the first one, telling humor could reduce boredom in learning in the classroom; the second, humor could break the stuck condition in the classroom; the third, students were feeling enthusiastic in learning when a teacher told humor in explaining the material; the fourth, students could easy to understand the lesson; and the last one, humor could maintain a social relationship.
\end{abstract}

Keywords: Teachers' Humor, Students' Enthusiasm, Humor's Functions.

\section{INTRODUCTION}

In Indonesia, many experts state that including humor when teaching can disturb the seriousness of learning, undermining the authority of the teacher or lecturer. In contrast, according to Darmansyah (2010), when students get pleasant stimuli from the environment, they will be more active and creative mentally and physically. Feeling comfortable when they enjoy laughing will provide an opportunity for memory to store information, both in the short-term and long term. Information is entered into the brain's memory that involves emotion in-depth, which will make it easier for them to remember back when it is needed.

In this case, I was interested in knowing whether humor can seize students' interest, create a positive way of thinking about the 
subject matter, and lower anxiety. Based on my preliminary observation and interview with some students focusing on how the teacher teaches in the classroom, I found that students often experience an unpleasant stimulus from the environment. Even an unpleasant atmosphere sometimes comes from the teacher. The teacher's behavior often makes them stressed, bored, and uncomfortable learning. Many students get difficulties caused their teacher was too severe in teaching English in the classroom; no jokes or language play can make the classroom fun. The teacher just explained the subject in her way without inserting humor in it, and students were instructed to do the exercises from the teacher. Thus, it made students get bored and less motivated to learn the subject taught.

The place in which this research took place was an English course place because teaching here did not need to be formal like in a school. I am concerned that if the teacher in the school applied the traditional or book-based method, I would not get accurate data. Furthermore, based on the information that I have got, an English teacher in ELC applies jokes in the classroom. Thus, I chose this place in conducting my research.

This research aims to investigate the teachers' humor in teaching English. Hopefully, it could become a piece of important information and a reference for the teacher or lecturer of English about teacher's humor.
Practically, it can be a strategy to create a fun way of teaching.

\section{LITERATURE REVIEW}

\section{Teachers' Humor in Teaching}

Humor originally is a Latin word referring to one of the four fluids of the body (blood, phlegm, choler, and black bile). Apte (2002) said that to observe, feel or convey humor, someone needs a sense of humor as well as a teacher. A teacher's sense of humor is the ability of the teacher to appreciate, create, and convey humor and laughter in doing his job without hurting another individual physically and psychologically. A teacher who has a good sense of humor can make the class enjoyable.

According to Baldwin (2007), "Humor is a social tool that provides an effective way to reduce stress, and increase relationships; also, humor protects social relationships when communicating negative information." Therefore, humor is the characteristic that makes it fun and makes people laugh. Humor in teaching can encourage a relaxed learning environment that motivates students to learn.

\section{Students' Enthusiasm}

In Indict dictionary, enthusiasm means passion, excitement, great interest. A passion for something that is in life. Enthusiasm comes from within, spontaneously, or through experience. Enthusiasm is a feeling excited toward something that happens. Of course, a positive response to something around us is expected because this response will affect daily behavior. Therefore, enthusiasm is feeling or showing 
intense excitement about something filled with or marked by enthusiasm.

Considering the definition, it can be seen that enthusiasm is the commitment of all person awareness (mind) and emotions (feelings) to the now moment. Whereas the values of respect, honesty, and consistency are primarily disciplines of the mind, enthusiasm is harnessing that discipline with the full range of positive emotions at our disposal into the now moment. Some students seem naturally enthusiastic about learning, but many need or expect their instructors to inspire, challenge, and stimulate them. Ericksen (1978) stated that effective learning in the classroom depends on the teacher's ability to maintain the interest that brought students to the course in the first place. Therefore, whatever level of enthusiasm students bring to the classroom will be transformed, for better or worse, by what happens in that classroom.

\section{Functions of Humor in the Classroom Interaction}

In an everyday context, we can understand why so much humor centers on what Cook (2000) has referred to as "vital" topics if we recognize that humor can help us cope with difficult situations. Humor stepped in to share emotions in a socially acceptable way as open expressions of sentiment fell out of fashion. As language teachers, considering both the challenging work conditions many instructors find themselves in and the stress students often feel in using a new language, the stress-relieving function of humor is essential.
Seeing the function of humor as a way of helping us make friends and maintain our affiliation with others can also not be underestimated. Non-serious uses of language are primarily social even though we may play with language and even utter things to amuse ourselves in solitary situations. We often use humor for entertainment and pleasure, and in doing so, we increase the positive effect among those sharing these diversions with us. The effect occurs not only with those with whom we have already known but with strangers as well. Humor is also essential for doing politeness.

\section{Research Questions}

1. What types of humor do the teachers use in teaching?

2. What is the function of teachers' humor?

3. What is the effect of teachers' humor on students' enthusiasm in learning English?

\section{METHODS}

The subjects of this research were one male English teacher and one female English teacher of the English Language Center (ELC). Besides these English teachers as research subjects, their students aged 17-23 at the Elementary level also participated in the study. The numbers of them are about 30 students. In collecting the data, this research took place in the classroom for six meetings during the classroom interactions, particularly in 90 minutes of English lessons for each teacher.

The research data were obtained by observing the learning and teaching activity in 
the classroom and interviewing the teachers and some students to know more about their perception of the learning process. The data were analyzed to identify the data from the observation, recorder, and interview. The data was analyzed through transcribed data into a written transcript and then identified, selected, and then classified based on the analyzing needs relevant to the research topic.

\section{FINDINGS AND DISCUSSION}

\section{The types of humor used by the teachers in teaching}

1. Joke

The teacher got to know his students in the first meeting by asking their hometown before starting the lesson because it was the first day of class. The expression "You and he sekamfrom yah" was classified as humor because "sekamfrom" was a combination between Makassar language "sekampung" means in the same village and English "from" which referred to hometown. Moreover, if it was combined between "sekampung" and "from," would become "sekamfrom." It was related to cultural context. The word "sekamfrom" was nothing after it was spoken and became people custom in Makassar saying that word. Thus, the term was being famous, and it has become something that sounds funny and made people laugh. Therefore, it was a kind of a joke when asking students hometowns.
2. Pun

At this time, the teacher wanted to twist the student's name, "Toma? I thought Tomat (tomato) hehe..or Tomas?". It was one kind of humor that is called Pun. Therefore, it could make students laugh because the word "toma" was a student's name, and "tomat(tomato)" was a fruit name. Thus, if the student's name was called by using a fruit name, it would sound funny for those who listened because the word "tomat" was not suitable for the student's name. Moreover, the name "Thomas" also made them laugh because it referred to a foreigner name, and the teacher imitated American style saying that word. Therefore, those expressions made students laugh at the time.

3. Funny story

The teacher explained the difference between 'will and be going to' by giving an example of her plan next week. The expression "I'll get married next week," "I have prepared my wedding gown," "I'm going to wear a white gown," and "menikahma minggu depan, saya undangko nach"(I'll get married next week, I invite you) was some statement of teacher's plan. Those students were laughing because of the higher imagination and nonsense told by the teacher.

\section{Humorous comment}

The teacher gave comments on the student's statement. The expression when a student said, "my mom will angry if I don't 
cook," and it was directly responded by the teacher saying, "I think there are lots of restaurants" contained spontaneous humor, and it made students laugh because if the student was hungry, she just came into a restaurant for eating and the mom did not need to be angry and complain her child if she did not cook. Thus, there were no problems with that. That was the point behind the teacher's expression.

5. Physical humor

The teacher was getting down starting the lesson, and the teacher instructed his students to have conversations by phone. The expression "do you have telephone hah?, meaning that the teacher wanted to make sure that his students knew the telephone was because his students come from the small village of Papua and seeing the teacher's gestures, putting his fingers (thumb and pinky) on his ear and it made students laughing.

6. Satire

The teacher's expression "yah you like American. Black American" was a joke when the teacher wanted to make role-play during the activities. Even though the teacher offended the student's skin, the student was exemplary and just smiled, and all the students also laughed. It might be because the teacher expressed with smiling. Therefore, the students thought that the teacher did not seriously about saying that.
Therefore, role play was able to make them happy and laugh.

7. Riddle

The teacher and students were playing a guessing game, guessing a famous person and the teacher tried to help students by concluding the students' statements. The statement "I am handsome" and "yah very handsome like me" when the teacher was repeating made students laugh because the teacher was full of confidence saying that.

Based on the result, the researcher can conclude that the teachers mostly used jokes in teaching in the classroom interaction; it was shown when teachers often inserted jokes at the beginning of the class, in strategic pause, and at the end of the class. The joke was easy to implement in any situation, and it can be applied to any topic.

\section{The function of teachers' humor}

\section{Stress relief/coping}

In the first meeting of the classroom observation, the researcher found that the teacher was trying to make a joke in the first meeting with his students to break the stuck condition in the classroom. In the first meeting, it viewed that, when the teacher got to know the student's hometown, he told a joke by saying "sekamfrom" because some of the students came from Puncak Jaya. "sekamfrom" is a language combination between Indonesian and English which has a meaning "in the same village." Before the 
teacher told a joke like that, students looked tired and sleepy, but most of the students were smiling and then laughing after telling the joke. Seeing that, this joke can reduce the students' tension

2. Draw students' attention

The result of the interview when the researcher asked the teacher or the subject in this research about the function of humor itself, according to the first subject, he said that humor could be used as an ice breaker when students were not in a good mood, or they were very reluctant with the material. Even they were sleepy or lazy to do activities, the teacher would enter some games or telling a joke to make them happy.

3. Facilitates communication and interaction

It could be seen that teacher could surf her students' world by humorous expressions. When the teacher asked a student about what method he used to cook "eggplant" and before the student answered that question, some other students laughed and made many comments about that. The expression "he plays it" means that there was no doubt or feeling shy of the students expressing that. Another example was when the teacher asked another student about "banana," Another student responded again by saying, "it's better to eat with coffee." These students were very enthusiastic about learning. The unique one of this extract was when the teacher asked about "eggplant," she asked male students, so it interacted with other students' attention to comment. Moreover, all students were young adults, and it could become an exciting topic for them to be laughed in the classroom. Thus, humor could build up relationships and develop communication between someone, and others including the relationship between teacher and students.

Furthermore, by seeing the interview with the subjects and the extracts of the recording, it can be concluded that the merrier function of humor was to facilitate communication and interaction between teacher and students or students with others. With humor, the teacher could create good communication and interaction with students to make the classroom more fun.

\section{The Effect of teachers' humor on students' enthusiasm in learning English}

1. Reducing boredom in learning

The student rated the teacher's humor as a strategy to make them not sleepy or feel bored during classroom interaction. Thus, inserting humor in the classroom could take out the boredom in the classroom

2. Breaking the stuck condition

The interview result indicated that the teacher who taught it was not serious, and the students could enjoy the lesson. If the students found difficulties in learning because the subject was complicated, it was time for the teacher to make the students happy. Therefore, the lesson would be easy for them to understand. Furthermore, the 
student also was free to speak include there were no hesitated in asking anything to the teacher. Therefore, it would create fun learning activities.

3. Feeling enthusiastic about learning

The students were happy, and they liked the teachers' humor because they could play while learning. So, the learning process was not too monotone, which could make them sleepy during the learning process, and the teacher also usually gave them motivation and spirit. Thus, the students were always enthusiastic about learning, and they would not be sleepy and give up on learning.

\section{Understanding the lesson easily}

The students were not afraid or hesitant to ask the teacher about the lesson, which they had not understood yet, because the teacher would explain the lesson again until the students understood it well and, of course, by inserting some jokes.

\section{Maintaining a social relationship}

The teacher and students could create a good relationship with humor. Also, if the students and teacher have had a closer or made a friendship, it would be easy for students to understand the lesson because there were no worries or stress when facing the subject. After all, the students like the teacher and automatically, they also would like the topic given.

Based on the present findings, the researcher found that joke was the most often used at the beginning and towards the end of the classroom interaction. For example: when the teacher got to know his students in the first meeting by asking their hometown before starting the lesson. The expression "You and he sekamfrom yah" (in the same village) was classified as humor. It was a kind of a joke when asking students hometowns. And most of the students were happy and welcomed the teacher's humor (Hoang Nguyen Huy Pham, 2014). The data from the observation has also shown that the teacher often used jokes before starting the lesson, at strategic pause, when explaining the subject and giving some examples. At the end of the class, the teacher inserted humor.

Besides jokes, the teacher also used puns when teaching-learning takes place. For example, the teacher sometimes played on the students' names such as "aa? Maizon? Maizon like a drinking water yah". This type of humor became an opportunity for the teacher to break the seriousness in the classroom. As Zijderveld (1983) describes, humor breaks down types of humor into the exploitation of either language, for example, pun, spoonerisms, logic, wit, elephant jokes, emotions, black humor, or the activities of everyday life (parody understatement) however this type of humor was hardly ever used in classroom interaction.

Figelson (1989) has put jokes and puns together in one type. Even though some researchers choose to distinct these types, those researchers said that telling a joke is different 
from telling a pun. And it could be seen from the observation that a pun would be more personal, whereas telling a joke is more of a performance.

Funny stories, humorous comments, and physical humor can be seen from nonsense, oddity, surprise, ignorance, awkwardness, contradiction, and misbehavior. The funny came out from the expression, utterances, or body language. The teacher in this research used a funny story in explaining the lesson. Example of a funny story, "and then I have prepared my wedding gown and then I have said to my friend and my friend ask me what gown are you going to wear in your wedding party and I say I'm going to wear a white gown.. ahaha menikahma minggu depan, saya undangko nach hehehe.." (I'll be married next week, I invite you). Those expressions were the teacher's plan. Those students were laughing because of the nonsense imagination told by the teacher.

Martin (2007) grouped these functions into three categories: Humor for stress relief and coping, humor for establishing and maintaining social bonds due to the positive emotions it evokes, and humor for prompting social action and exerting influence over others. Although in this study, the researcher also found three functions of humor in the classroom, the functions were different from the function divided by Martin (2007). The researcher found three other functions. Only one of them has the same function as Martin (2007). They were: coping with stress, drawing students' attention, and facilitating communication and interaction.
Coping stress is one of the functions of humor in this data. Another study by Flowers (1995) indicated that humor could decrease stress for students. It means that humor could give a benefit that is significant to omit psychological pressure. For example: in extracts (1), (2), (10), (11), (12), and the interview with the teacher. In classroom observation, when the teacher got to know the student's hometown, he told a joke by saying "sekamfrom" because some of the students came from Puncak Jaya. "sekamfrom" is a language combination between Indonesian and English which has meaning "in the same village." Before the teacher told a joke like that, students looked tired and sleepy, but most of the students were smiling and then laughing after telling the joke.

Furthermore, Boerman (2000) concluded that every successful teacher should have prepared jokes or anecdotes. It means that a humorous teacher is expected to create fun learning. Thus, he could make the classroom alive if the learning condition is not attractive.

Another function of the teacher's humor was to draw students' attention, such as extracts (2), (4), (5), (6), and the interview. It could be seen that teacher could explore her students' world by humor expressions in extract two. When the teacher asked a student about what method he used for cooking "eggplant," and before the student answered that question, some other students laughed and made many comments about that. The expression "he plays it" means that the students were interested in 
following the lesson.Another function of the teacher's humor was to draw students' attention, such as extracts (2), (4), (5), (6), and the interview. It could be seen that teacher could explore her students' world by humor expressions in extract two. When the teacher asked a student about what method he used to cook "eggplant," and before the student answered that question, some other students laughed and made many comments about that. The expression "he plays it" means that the students were interested in following the lesson.

Treft and Blakeslee (2000), in their study which is related to library instruction, found that humor is the best way to make the boring subject more interesting for students as well as for teachers. An exciting subject will increase a better learning objective.

The other function of teacher's humor that the researcher found in this study is facilitated communication and interactions. This function was presented in the extracts (7), (8), (9), (9), (10), (11), and (12). This function occurred when the teacher taught in the classroom.

There were five effects of the teacher's humor and enthusiasm in learning English. They reduced boredom in learning; humor could break the stuck condition; feeling enthusiastic in learning; understanding the lesson easily, and maintaining social bonds.

Referring in finding previously in Kustanto (2010) in his thesis, indicators of students' enthusiasm are the presence of a response, attention, concentration, awareness, and willingness incurred on students without coercion or messengers, which was followed by a desire to get involved in student activities and the learning process. In this part, the researcher described the effects of teachers' humor related to the students' enthusiasm in learning English. The first effect was humor could reduce boredom in the classroom. It could be seen from the interview with the student that the student rated the teacher's humor as a strategy to make them not sleepy or feel bored during classroom interaction. In other interviews, it also could be seen that students preferred the teacher with a higher voice than the teacher with a slower voice because the slower voice would make them sleepy in the classroom. Furthermore, the students also liked when the teacher gave some games while learning because it could make them enjoy the learning and want to learn again because learning was fun.

The second effect was humor could break the stuck condition. Humor could be used to break the stuck condition, when the teacher saw the students were serious or the material given was hard, so it was time for the teacher to insert a kind of humor or make the students happy. Therefore, the lesson would be easy for them to understand. Furthermore, the student also was free to speak include there were no hesitated in asking anything to the teacher. Therefore, the students would be active and responsive in responding to the teacher and other students when giving explanations. 
The following effect was feeling enthusiastic about learning. If the students were enthusiastic about learning, it would be viewed from their performance and competence. From the interview with some students, it could be seen that the students were happy, and they liked the teachers' humor because they could play while learning. Therefore, students could enjoy the whole learning activity, and they have had awareness in learning by doing the homework given.

The fourth effect was students got easy to understand the lesson. Some students, who have a sense of humor in themselves, would be delighted if the teacher also is the typical person who likes humor. Some students said that they could not catch the material if the teacher were too serious in teaching in the classroom happened in many places. Some students said that they could see the explanation, and they responded to the teacher.

The last effect was maintaining social bonds. Based on the interview with some students, it could be seen that the teacher and students could create a good relationship and also if the students and teacher have had closer or make a friendship, it would be easy for students to understand the lesson because there were constantly listening to the material given by the teacher, not crowded when the teacher was explaining the lesson and quickly understand.

\section{CONCLUSION}

Based on the findings and the discussion in the previous part, the researcher concludes that:

1. There were seven types of humor used by the teachers during the teaching and learning process. They were joke, pun, funny story, humorous comment, physical humor, satire, and riddle. And the most used in the classroom was a joke.

2. The researcher found three functions of teachers' humor: coping with stress, drawing students' attention, and facilitating communication.

3. There were five effects of teachers' humor on students' enthusiasm in learning English in the classroom; the first one, telling humor could reduce boredom in learning in the classroom; the second, humor could break the stuck condition in the classroom; the third, students were feeling enthusiastic in learning when the teacher told humor in explaining the material; the fourth, students could understand the lesson easily; and the last one, humor could maintain the social relationship.

Based on the conclusions presented above, several suggestions are made as follows:

\section{For teachers}

1. The teacher should use appropriate humor during the classroom interaction because humor can give a benefit that is significant to reduce psychological pressure. 
2. The teacher should create a fun learning activity when humor is inserted in learning. So that the students can morpay moretention to the teacher and the class can be more effective in learning.

\section{For other researchers}

This research only involves two English teachers in ELC Education Makassar. Consequently, the result of this research may not apply to other teachers and educational levels. Further research with a broader scope of study is expected to give a valid generalization.

\section{REFERENCES}

Apte, M.L. (2002). Humor and Laughter: An Anthropoligical Approach (4th ed.). London: Cornell University Press.

Baldwin, E. (2007). Humor Perception: The Contribution of Cognitive Factors. Psychology Dissertation.

Boerman, C. W. (2000). Humour Your Students. Education Digest. 65(5), 56-62.

Cook \& Guy. (2000). Language Play, Language Learning. Oxford: Oxford University press Corduas, Marcella, Allyson Eggleston, and Salvatore Attardo Forthe

Darmansyah, S.T. (2010). Strategi Pembelajaran Menyenangkan Dengan Humor. PT Bumi
Aksara.

http://m.kompasiana.com/post/read/54 3116/1/belajar-mengajar-butuh-humorbukan-horor-.html

Erikson. (1979). Personality Theory, 137-169. Kanisius, Yogyakarta

Figelson, S. (1959). Mixing Mirth and Management. Supervision, 50 (11): 6-8

Flowers, J. (2001). The Value of Humour in Technology Education Technology Teacher, 60, 10-13. (http: // www.tomveatch.com / else / humor / summary.html) accessed

Kustanto, F. (2010). Peningkatan antusiasme siswa dalam pembelajaran Matematika melalui metode participatory learning Pada pokok bahasan bangun ruang sisi datar. Universitas Muhammadiyah Surakarta.

Martin, R.A. (2007). The Psychology of Humor: an Integrative Approach. Burlington, MA: Elsevier Academic Press.

Miles, M.B., Huberman, A.M., \& Saldana, J. (2014). Qualitative Data Analysis: A method sourcebook. USA: SAGE Publications.

Nguyen, H. (2014). The use of humor in EFL teaching: A case study of Vietnamese university teachers' and students' perceptions and practices. University of Canberra, Australia. 